\title{
The Meaning of Sacred Space on the Architecture of the Historic Mosque Case Study of Masjid Jami 'Al Mukarromah Kampung Bandan
}

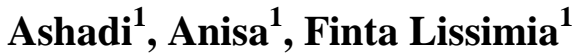 \\ ${ }^{1}$ Department of Architecture, Universitas Muhammadiyah Jakarta, Indonesia \\ ashadi@ftumj.ac.id
}

\begin{abstract}
The building of worship is a building that has sacred spaces as a container of its activities. The case study taken in this research is the historic mosque which is often referred to as a sacred mosque because of the tomb of Habib Islamic syiar carrier. The existence of the tomb inside the mosque is what makes the mosque visited by pilgrims and pilgrims and has various activities related to worship and pilgrimage. The purpose of this research is to get a conclusion about the sacred space and its meaning in Masjid Jami 'AlMukarromah Kampung Bandan. This research uses descriptive interpretive method. Field observations were conducted by, first, observation of study subjects, ie by observing the activities undertaken at Masjid Jami 'Al Mukarromah Kampung Bandan. From activity observation can be found sacred activity and profane activity. Second, observing the spaces used sacred activities that are done in the mosque. Interviews were conducted with the main sources and direct descendants of Habib Alwi bin Ali As-Syatiri. The result of this study is that the sacred space of the Jami 'AlMukarromah mosque has a clear definition and is reflected in its physical form. The sacred space used is the main prayer room as the sacred space which has the highest hierarchy. The main prayer room is part of the expansion building. Sacred space of pilgrimage is on the part adjacent to the tomb and the original part of the mosque which is often called the Nine pillars. The area adjacent to the tomb is an important area so the expansion or renovation of the mosque does not change the original form. The sacred space used for the haul activity is the same as the sacred space for pilgrimage, that is, in the section adjacent to the tomb and pillar of nine.
\end{abstract}

CC 2018 IJBESR. All rights reserved.

Keywords: Sacred Space, Meaning, Historic Mosque, Masjid Jami’ Al Mukarromah

\section{Introduction}

Masjid Jami 'Al Mukarromah located in Kampung Bandan North Jakarta is one of the objects of cultural heritage that is protected by law. The uniqueness of the mosque Jami 'Al Mukarromah compared with other historical mosques there are two that is located the mosque right on the edge of the highway and the tomb of habib in this mosque which became the destination of pilgrimage. Initially in this place there are two tombs of Habib namely Habib Mohammad Bin Umar AlQudsi and Habib Ali Bin Abdurrahman Ba'Alawi. Then Habib Abdurrahman Bin Alwi
Asy-Syatiri built a mosque around him in 1879 AD His son named Habib Alwi bin Abdurrahman bin Alwi As-Syatiri who later built the mosque as a mosque. The original mosque building next to the tomb is still in good condition. In addition to being used for prayer, the mosque is also used as a pilgrimage destination. The mosque is also known as the sacred mosque because of the habib grave as the main purpose of the pilgrimage.

The building of worship which has a sacred value is determined by its religious value, cultural background, symbolization and spiritual purpose, since the building which has 
sacred values will be emitted at the built place to generate meaning from ritual symbols and accommodation on the belief system adopted by the local community [1]. Historic buildings in this mosque equipped with a tomb, will usually be an icon of an area. In other words Jami 'Al Mukarromah Kampung Bandan's historic mosque with Habib's grave can be a place in the area. This is in line with the Mosque-Tomb-Tower complex of the Holy Tower which became a place in the area of the Holy Old City because it is not only historical but also valuable value culturally and architecturally [2].

Sumalyo (2006) [3] revealed that in essence, the mosque is a place to do all activities related to obedience to God alone. Therefore, the mosque can be interpreted further, not just a place of prostration, purification, place of prayer and bertayamum, but also as a place to carry out all the activities of Muslims related to obedience to God. Based on this background then conducted a study to determine the sacred space contained in Masjid Jami 'AlMukarromah Kampung Bandan. Sacred space is traced through: (1) identification and description of the main activities carried out in the mosque; (2) identification and description of spaces used for the main / sacred / sacred activity; (3) analysis of the meaning of sacred space based on the activity and the form of space. Architecture Masjid Jami 'Al Mukarromah Kampung Bandan is a cultural product that contains tangible and intangible elements, hence in this research will be used descriptive interpretative approach. Descriptive approach aims to describe the activities undertaken along with the existence of sacred spaces. Interpretative approach is a meaningful process of a value that exists in the object of research through the interpretation of the meaning of sacred space in the mosque.

\section{Material and Methods}

\section{Sacred Review}

The issue of sacrality was first put forward by Rudolph Otto in his book Das Heilige (the sacred). As a Theologian and historian Otto traces the religious experience of the psychology. Departing from the opinion of Otto then Eliade an expert Historian and Philosopher perform a search of sacredness with a structuralist approach. Eliade put forward the issue of sacred orientation. The study of this sacred orientation consists of three parts; First Axial orientation; Second Geometric orientation; Third Location orientation [4].

In the book of Sacral and Profan, Eliade classifies the sacred ideas, namely Hirofani and Axis Mundi as embodiments of the Axial Orientation. Sacred space will be created when a sacred thing is manifested into reality, this is called the hirofani. Each of these sacred spaces is characterized by a hirofani, so this sacred presence sets apart the cosmic environment that surrounds and makes it different. This Hirofani becomes a new order that manifests the center of the cosmos marked by Axis Mundi which becomes the axial axial axial shaft [5].

Eliade [5] also said that sacredness can not be created by human and human effort can not have the freedom to determine the sacred location. Humans can only search and find with mysterious signs [5]. The embodiment of the sacred idea is often influenced by the place I location factor, where something has happened. Humans as religious beings want to create a sacred form of appreciation and gratitude to the creator, God, embodied in geometric forms oriented above or in the sky. So it is referred to as Geometric Orientation into container or shape, cylinder, cube, pyramid, circle, square and triangle. 
Based on Eliade's thesis, then Jones a religious architect goes on and develops Eliade's thinking by adding importance to the hierarchy aspect. The hierarchical aspect according to Jones is divided into two forms of hierarchy and hierarchy of activities, all these hierarchies can not be separated from the social, political and cultural, but also the hierarchical division can be horizontal and vertical.

The architectural orientation is the direction designated by the imagination of the sacred being. The imagination of this sacred being is usually placed in a direction considered sacred by its devotees. Hierarchy is the order or level of the imagination of the sacred being. Starting from the most important or sacred [4]

Jones [6] grouped sacred ideas in architecture as orientation and hierarchy. Jones classifies the hierarchy into 2 namely the hierarchy of forms and hierarchy of activities. A hierarchy of forms is architecture as commemoration or architecture as the embodiment of ritual and disclosure of events or presence, while the hierarchy of activities is a architecture as ritual context or architecture as a celebration associated with ritual.

\section{Kampong Bandan}

Kampong Bandan is one of the urban villages located in the Ancol region, Pademangan subdistrict, North Jakarta. This village is close to Sunda Kelapa Harbor. Based on the history books record, the origin of why this area is called Kampung Bandan is from the word "Banda" which is the name of the island in the Maluku region. In the time of the Dutch colonial government in 1621 , the region was used as a slave shelter from the Moluccas. At that time many slaves were housed in Batavia, as well as from the Moluccas, also from the areas of Sumatra, Java, Bali, Manggarai, Buton, Sulawesi, Sumbawa, Mandar, and Papua [7][8].
In addition, Kampung Bandan is also a change of speech from the word "pandan". In the past in this village many pandanus trees grow, so people call it by the name of Kampung Pandan, which turned into Kampung Bandan. Achmad Ruchiat in his book The Origin of Place Name in Jakarta writes that Kampung Bandan or Kampung Banda or Kampung Pandan is a small colony grouped by VOCs in a place. Almost all Kampung Bandan residents came from Banda and were brought to Batavia as slaves. (Ruchiat, 2018). While Heuken in his book Old Mosques in Jakarta. In the book mentioned that there is an old mosque called Al-Mukaromah in which there is an old grave typical of the Banda [9].

Kampung Bandan then grew into densely populated and rundown neighborhoods until today. Kampung Bandan has an area of 6.3 hectares and is bordered by Jalan Lodan Raya and the toll road on the south side and Ancol Village neighborhood adjacent to Sunda Kelapa Harbor on the north side. The existence of Kampung Bandan is unique because it is in a modern environment, but the face and culture of the village is still left. Physically, the spaces in it show the character of the village that still survive in the middle of the crush of the power of the metropolitan space. Kampung Bandan is inhabited by about 100 heads of families is a livelihood as a motorcycle taxi, laborers, employees or food traders. Inside this area, Kampung Bandan has a historic mosque which is the attraction of the region as a pilgrimage place called Masjid Jami 'Al Mukaromah Kampung Bandan [10]

Kampung Bandan has an area of 22.1 ha based on Jakarta regulation No. 1 of 2014 attachment III-3 on Spatial Detail Plan and Zoning Regulation (Anonymous, 2014). Based on interviews in get data that Ancol urban village is divided into $7 \mathrm{RW}$. Kampung Bandan is located in the area of RW 2. RW 2 consists of 15 RT with the number of KK about 2090 
families. The male population is 4277 inhabitants and 2988 inhabitants.

\section{Masjid Jami' Al Mukarromah Kampung Bandan}

Al-Mukarromah Mosque is one of the old mosques in Jakarta built in the 18th century. In Arabic, the name of this mosque has a noble meaning or a glorified. At first called the Great Kampung Mosque [11].

Inside the Mosque of Jami 'Al Mukarromah Kampung Bandan there are three tombs of great scholars namely Habib Mohammad Bin Umar Al-Qudsi (died on 23 Muharram 1118 H), Habib Ali Bin Abdurrahman Ba'Alawi (died 15 Ramadhan $1122 \mathrm{H}$ ), and Habib Abdurrahman Bin Alwi Asy-Syatiri (d. 18 Muharam $1326 \mathrm{H}$ ), founder of the mosque. these three tombs are the oldest tombs in Jakarta. Meanwhile, another tomb is also there, the tomb of Habib Ali Bin Alwi bin Abdurrahman Asy-Syatiri who died on Friday, August 13, 2010. In 1947, the building was expanded into a mosque that can accommodate many pilgrims to worship and pilgrims tomb. This mosque became the historical significance of this kampong which was restored and expanded in 1972 by the Museum and History of DKI Jakarta and is maintained until now [10][12].

Activities that occur at Masjid Jami 'Al Mukarromah Kampung Bandan can be observed based on daily, weekly, monthly and yearly activities. For example, five-day prayer activities, chanting, bazaars, two Idul Fitri holidays and Eid al-Adha, the celebration of the big days of Islam, Haul, Maulid and the pilgrimage activity of the habib tomb.

Masjid Jami 'Al Mukarromah Kampung Bandan has two forms of buildings: new buildings on the front (west side) and old buildings on the back (east). The land area of this mosque complex is actually almost 1 hectare, but since the 1970s has begun to work a lot of migrant residents to be a place to live. In 1998, Jakarta Provincial Government finally built a barrier wall around the mosque area so that the remaining land will not decrease. Provincial Government of DKI Jakarta itself in 1972, has entered the Mosque Jami 'Al Mukarromah Kampung Bandan as one of the cultural heritage buildings must be protected. (http://www.beritasatu.com/destinasi/129951melongok-makam-tertua-di-masjid-kramatkampung-bandan.html).

Since its establishment about 134 years ago, Masjid Jami 'Al Mukarromah Kampung Bandan has undergone three times restoration. The first restoration was in 1979-1980, the second was in 1989-1990, and the last was in 2000-2001 where the exaltation was done in the mosque building. Despite extensive refurbishment, the building design still retains the first building form, in order to preserve the authenticity and value of the history of the mosque itself. The restoration fund comes from the government every ten years, while for routine maintenance funds, mosque officials get it from Friday prayers and pilgrims. In 2006-2007, the mosque was flooded. After elevated about one meter, until now the mosque is not flooded again. (http://www.tribunnews.com/ramadan/2014/07 /02/membaca-sejarah-masjid-al-mukarromahdi-kampung-bandan).
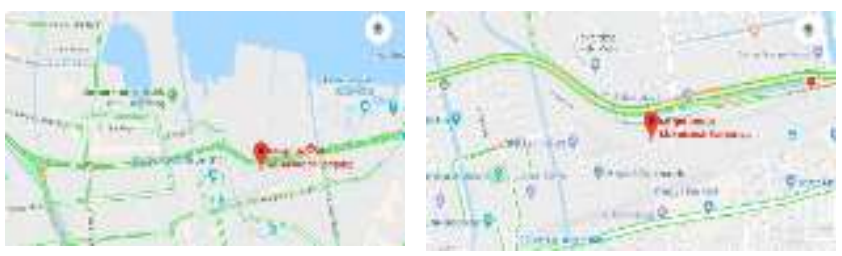

Source: Google Map, 2018

Figure 1. Location of the mosque Jami 'AlMukarromah 


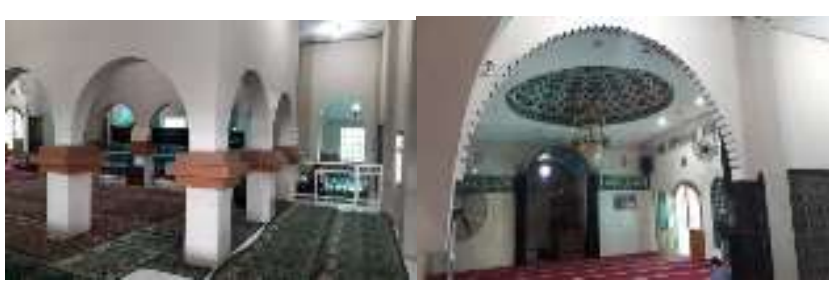

Figure 2. The original Jami 'AlMukarromah Mosque (left) and expansion (right)

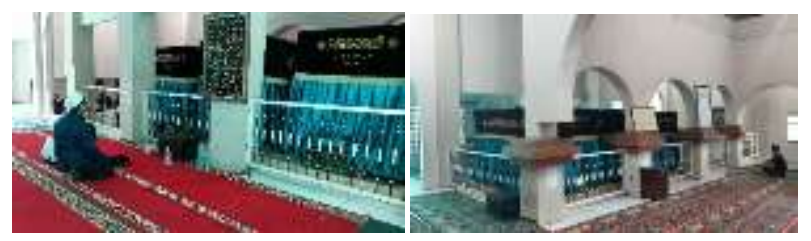

Figure 3. Tomb of Habib as a Pilgrimage Destination

\section{Research Methods}

This research uses descriptive interpretive method. Recording of data in the field is done through field observation and interview. Field observations were conducted by, first, observation of study subjects, ie by observing the activities undertaken at Masjid Jami 'Al Mukarromah Kampung Bandan. From activity observation can be found sacred activity and profane activity. Second, observing the spaces used sacred activities that are done in the mosque. Observation completed with interview. Interview with the main source who is the direct descendant of Habib Abdurahman bin Alwi Asy-Syathri named Habib Alwi bin Ali As-Syatiri.

The following Eliade and Jones [5][6] arguments serve as a tool for analyzing: (1) Sacred space will be created when something sacred is manifested into reality (hirofani); (2) this sacred presence sets apart the cosmic environment that surrounds and makes it different; (3) This Hirofani becomes a new order that manifests the center of the cosmos marked by Axis Mundi which becomes the axial axial axial shaft; (4) sacredness can not be created by human effort and man can not have the freedom to determine sacred location;
(5) The embodiment of the sacred idea is often influenced by the place / location factor, where something has happened; (6) Orientation of architecture is the direction designated by the imagination of the sacred being. The imagination of this sacred being is usually placed in a direction considered sacred by worshipers; (7) Hierarchy is the order or level of the imagination of the sacred being. Starting from the most important or sacred. This section should provide sufficient detail to allow the work to be reproduced. Methods already published should be indicated by a reference: only relevant modifications should be described

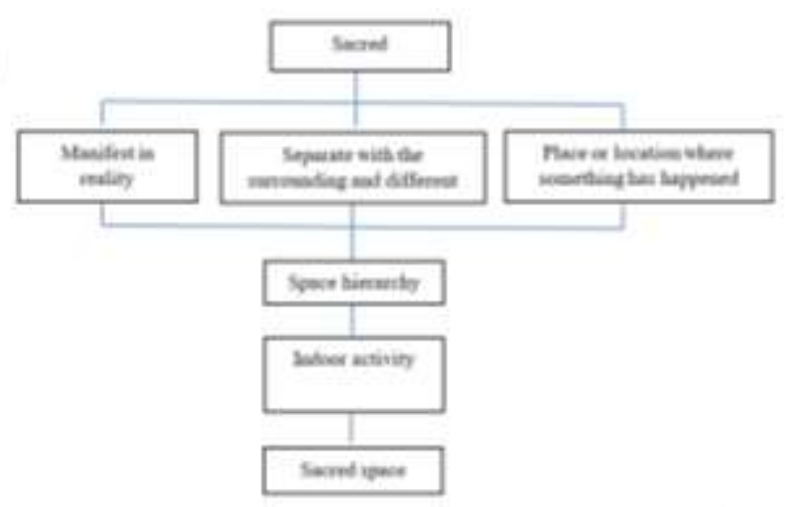

Figure 4. Construction of Sacred Space Thinking

The construction of the sacred space thought is built on the previously described Mircea Eliade and Jones theories [5][6]. Based on the construction of the thought and adapted to the research objectives, the following steps are carried out: (1) identify and describe activities undertaken in the mosque; (2) identify and describe sacred activities conducted in the mosque; (3) identify and describe the spaces used for sacred activities in the mosque; and (4) interpreting the sacred space to reveal meaning based on its activity and spatial form. 


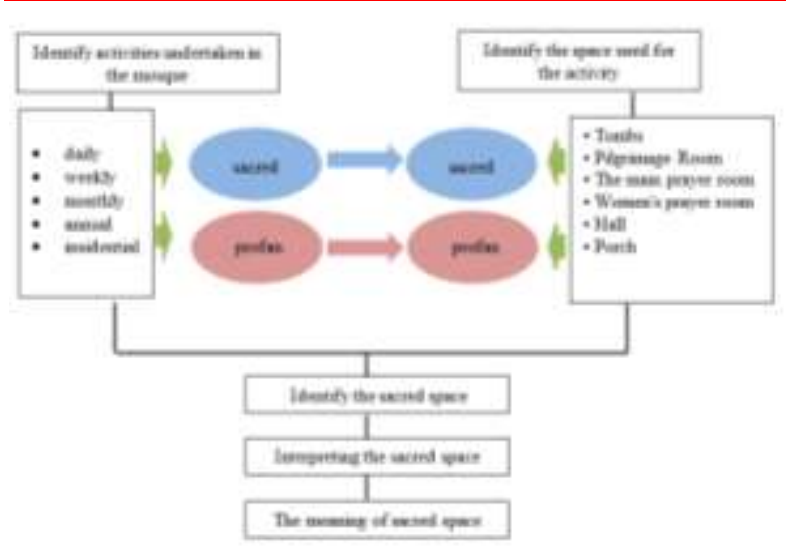

Figure 5. Research Framework

\section{Results and Discussions}

\section{Identification and Description of Activities at Masjid Jami 'Al Mukarromah}

Just like a mosque, the Jami 'AlMukarromah Mosque also has routine activities that can be observed and identified. The thing that distinguishes this mosque with other mosques is the existence of activities other than the prayer is due to the tomb and pilgrimage activities in this mosque.

The mosque is located just on the edge of the main road of Jalan Lodan Raya, the back of the mosque is a dense settlement, while the other environment is the warehouses. Identification of activities at Masjid Jami 'Al Mukarromah includes daily, weekly, monthly and yearly activities. Daily activities in the mosque is a five-time prayer and pilgrimage tomb. Five obligatory prayers are performed in congregation. The pilgrimage to this mascid is the tomb of Habib Mohammad bin Umar AlQudsi, Habib Ali bin Abdurrahman Ba 'Alwi, and Habib Abdurahman bin Alwi AsySyathiri. In addition to these 3 tombs there is still the tomb of Habib Ali bin Alwi bin Abdurahman Asy-Syathiri. The four tombs are lined up inside the original mosque area. While on the porch / front porch adjacent to JL Lodan there are 2 graves whose headstone is not named.
Prayer activities 5 time congregation performed by the surrounding community and the pilgrims. On weekdays, the number of worshipers 5 days of prayer is not much. If the congregation is only local people then the number of pilgrims about 2-3 shaf $( \pm 40-50$ people). The pilgrimage activity of the habib tomb takes place every day. Dozens of pilgrims come to this mosque to pray from morning to evening because the mosque is open 24 hours for the pilgrims. Usually pilgrims come in groups using a car or bus. Then they will pray together around the tomb and do the prayers in this mosque.

Pilgrims will come more on Sundays, national holidays, and Friday nights. That's why in the recording of data identified the weekly pilgrimage. The most hectic pilgrimage by month is on Sha'ban Moon. In the month of Sha'ban pilgrims who come in one day reach 30 bus pilgrims. Pilgrims are not only from around Jakarta but also from Jadebotabek, Java (Jabar-Jatim-Central Java) and Sumatra.

Identification of weekly activities at Masjid Jami 'AlMukarromah Kampung Bandan found several things: (1) Friday prayer; (2) Friday night cemetery pilgrimage; (3) the night bazaar (bazaar); and (4) Pengajian Pekanan. Friday prayers are held in the mosque is attended by about 1,000 pilgrims and meet the entire mosque. Jum'at Friday prayers of nearly 100\% of these men are from local residents and pilgrims. Many pilgrims who come Friday night to make pilgrimage and pray as well as following Friday prayers the next day. That's why in the mosque is provided space without walls are often called the hall or porch / terrace foundation used for the stay of the pilgrims.

While on the eve of Monday, outside the mosque held impromptu market called the bazaar. The goods sold in this bazaar vary, there are clothes, sandals, prayer equipment, kitchen utensils, etc. The traders come from West Java, Tangerang, and Bogor. They are a 
group of bazaar traders who always move from day to day. In addition to selling on the eve of Monday, this merchant also enliven the area around the Masjid Jami 'Al Mukarromah when there are haul, mawlid and other events of other Islamic days.

The Quran study discusses various materials. On Friday night filled with reading yasin (yasinan), pengajian night senin is pengajian fiqh, delivered by Habib Alwi, and pengajian Thursday night is Yasinan with foundation. This recitation is done after the prayer isya. Monthly activities at the Jami 'Al Mukarromah Mosque do not exist. This is the same as the Outside Stem Mosque, which has no monthly activity. Usually in historic and sacred mosques such as Walisanga mosques every month (exactly 35 days based on Javanese market day), which falls on Friday Kliwon night or part of mosque on Friday Legi, tomb pilgrimage more in number compared to ordinary days or regular Friday nights [12][13].

Table 1. Identification of Activities at Masjid Jami 'Al Mukarromah

\begin{tabular}{|l|l|l|}
\hline Period & Activity & Category \\
\hline daily & Pray five times & sacred \\
\hline & pilgrimage & sacred \\
\hline weekly & Jum'at prayer & sacred \\
\hline & Friday night pilgrimage & sacred \\
\hline & The evening bazaar & profan \\
\hline & Quran recitation & profan \\
\hline monthly & - & \\
\hline yearly & Prayers tarawih & sacred \\
\hline & Eid Al-Adha Prayer & sacred \\
\hline & Eid prayer & sacred \\
\hline & Haul 12 Ramadan & sacred \\
\hline & Haul Habib and Maulid & sacred \\
\hline & breaking the fast together & profan \\
\hline & yearly pilgrimage & sacred \\
\hline
\end{tabular}

Source: Author's Analysis

The identification of the annual activities of Masjid Jami 'Al Mukarromah includes: (1) Tarawih prayer in Ramadhan, Eid al-Fitr prayer and Eid al-Adha; (2) haul Habib in Ramadan (12 Ramadhan), Haul Habib and
Maulid of Prophet Muhammad SAW, (30 annual pilgrimages, and (4) breaking daily fasting during Ramadhan month Based on information from Habib Alwi, tarawih jamaah the mosque is the most crowded at the beginning of Ramadhan, which fulfills the mosque even to the outside of the mosque.The most crowded Jamaah around 2000 pilgrims.Halat prayers Eid al-Fitr numbered about 5000 people, as well as with Eid ulAdha haul Habib held 2 times in 1 year ie on month The mawlid, together with the memorial of the maulid, and on the 12th of Ramadhan month, Haul Habib which is held simultaneously with the Maulid commemoration is attended by 5000 pilgrims, as well as Idul Fitri, while the haul habib in Ramadan is followed by around 2000-2500 people.

\section{Sacred Space Identification and Description}

Identification and description The sacred chamber is preceded by the identification and description of the overall space contained and used in this mosque. In addition, the description of the sacred space is also related to the activities undertaken within the mosque. In accordance with Eliade's theory that 'Sacred space will be created when a sacred thing is manifested into reality, this sacred presence sets apart the cosmic environment that surrounds and makes it distinct' it is necessary to discuss the analysis of sacred activity and the space used for the activity. The sacred activity of the Jami 'AlMukarromah mosque has been discussed in the previous section. In this section will be discussed spaces.

Similarly, Eliade's opinion that 'The embodiment of sacred ideas is often influenced by the factor of place / location, where the occurrence of something' in accordance with the condition of Masjid Jami 'AlMukarromah which became different from other mosques and is considered sacred because of the tomb of Habib which is the intermediary of Shiar Islam. 
Prayer activities performed at this mosque include; (1) praying in congregation 5 times; (2) Friday prayers of the congregation; (3) Tarawih congregational prayer; (4) prayer of the congregation iedul fitri and iedul adha. The obligatory five day prayers are from the surrounding community and the pilgrims. Five-day prayers in congregation on weekdays are done at the main prayer room measuring about $100 \mathrm{~m} 2$. On weekdays for dhuhur prayers and ashar worshipers from the surrounding environment amounted to about 2-3 shaf ( $\pm 40-50$ people). At night jama'ah increases by using the main prayer room as a place of prayer. Jamaah most are prayers maghrib and isya that meet the main prayer room. If the place is not sufficient then used also the expansion of mosques and tombs or adjacent to the place of pilgrimage. Place of prayer female pilgrims are next to eat, which is also used as a place to pray the pilgrims. The total capacity of this mosque ranging from the main hall to the place of pilgrimage and hall and porch is a maximum of 1000 people. The area called the hall is an expanding building of the mosque towards the back and sides that are not walled.

At the time of Friday prayers attended by 2000-2500 Jamaah. Because of the mosque's capacity of 1,000 pilgrims then Friday prayers to the halls, terrace foundations, even down to Lodan street. The pilgrims who are accommodated in the mosque are only half of the total number of pilgrims. the weekly pilgrimage activity is a pilgrimage that is usually done on holidays (Sunday) or Friday night. On the eve of Friday after the prayer Isya also many pilgrims who come. The pilgrims sometimes rest in the hall and remain in the mosque until dawn. Pilgrimage on weekends or big day in a day can reach 10 buses.

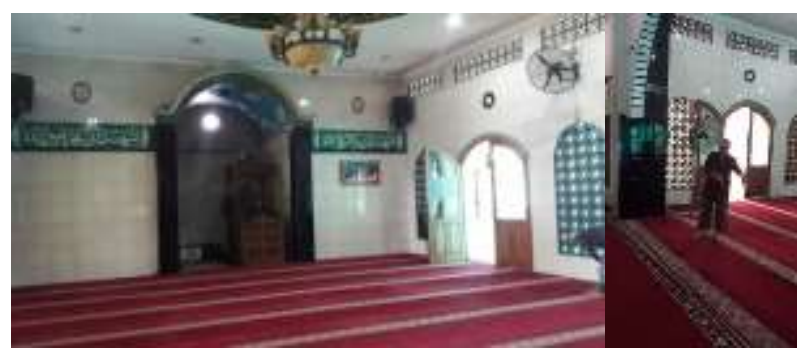

Figure 6. The main prayer room (left); border of original mosque and expansion (right)

Based on information from Habib Alwi, the number of pilgrims tarawih in this mosque most crowded at the beginning of ramadhan Jamaah meet the mosque even to the outside of the mosque. Jamaah most crowded around 2000 pilgrims. The pilgrims filled the mosque, down to the hall and the sidewalk and the slow lane at Lodan Road. Jamaah most is the time of prayer iadul Fitri. Eid al-Fitr prayers numbered about 5000 people, pilgrims meet mosques, roads even to the bridge.

In addition to the prayer activities that have been described above, one of the other sacred activities is the pilgrimage and haul habib. Around this mosque is buried 4 habib namely Habib Mohammad Bin Umar Al-Qudsi, Habib Ali Bin Abdurrahman Ba'Alwi, Habib Abdurrahman Bin Alwi Asy-Syatiri and Habib Alwi bin Abdurrahman bin Alwi As-Syatiri. Pilgrimage activities are done every day and housed in a grave side room. This space is also used for prayer when the main room is not enough to accommodate the congregation. According to Habib Alwi, the managers of the mosque expect a clear separation of the area between the mosque with the place of pilgrimage so that the two activities are equally well run. But the current conditions are not possible because during Friday prayers, tarawih and ied, the side of the tomb is still used for prayer. A special place to pray for pilgrims has been given a special mark by the mosque administrator. That is the presence of a green carpet placed next to the tomb area. 
Dozens of pilgrims come to this mosque to pray from morning to evening because the mosque is open 24 hours for the pilgrims. Usually pilgrims come in groups using a car or bus. Pekanan pengajian done after prayer in the mosque's main prayer room. This study is usually followed by 200 worshipers.
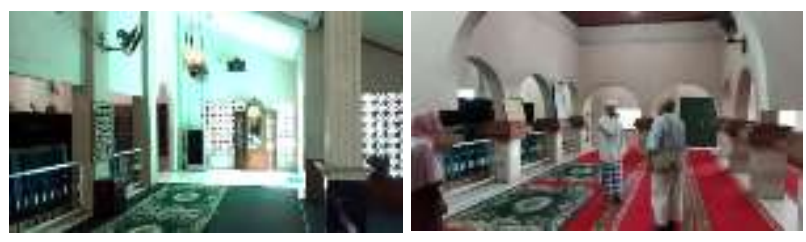

Figure 7. Expansion of mosque used by women prayers and shrines (left); The original mosque of the Nine pillars used the pilgrimage site (right)

Warning haul for Habib done a year 2 times in the month of Mawlid and the month of Ramadan. In the month of Maulid, haul is held simultaneously with the memorial of maulid, and in the month of Ramadhan haul held on 12 Ramadan. Jamaah who follow the warning haul Maulid more than haul ramadhan. Because haul months Maulid at once combined with the celebration of the Prophet Muhammad SAW. Haul Habib conducted simultaneously with Maulid commemoration followed by 5000 worshipers. Haul habib held in Ramadan followed around 2000-2500 people.
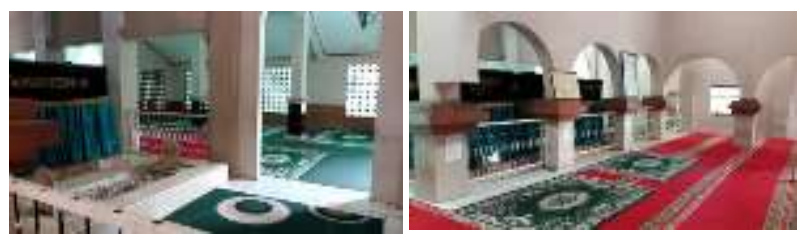

Figure 8. Special Place Of Daily Pilgrimage, Weekly, And Haul

Activities when Haul Ramadan is done starting after the ashar prayer until finished around 10$11 \mathrm{pm}$. The series of haul ramadhan activities include ashar congregational prayers followed by pengajian and sholawat reading. When the maghrib adzan reverberate, the pilgrims open together with takjil and maghrib prayers in congregation. After the maghrib prayer then the meal together and rest while waiting for isya. After prayer isya then resume the main event haul namely reading manaqib and pilgrimage tomb together. After the core event is completed then continued with tarawih prayer and lecture. In the month of Ramadan, this mosque also organizes an iftar together, followed by the pilgrims and the surrounding community. Open together is done in the mosque hall and the foundation's terrace.

Bazaar is an activity that is not sacred value, but always there and enliven the mosque. The bazaar is held every Monday by traders. After the ashar time on Sunday, the traders had prepared the place. The place used for the bazaar is the sidewalk and the slow lane that is in front of the mosque. The management of the mosque does not permit traders to enter the mosque area for order and to be devoted to the pilgrims.

Table 2. Identification of Space used in Masjid Jami 'Al Mukarromah

\begin{tabular}{|c|c|c|}
\hline Period & Activity & Place \\
\hline \multirow[t]{2}{*}{ daily } & Pray five times & $\begin{array}{l}\text { The main room of the } \\
\text { mosque }\end{array}$ \\
\hline & pilgrimage & $\begin{array}{l}\text { Tomb and prayer room } \\
\text { expansion }\end{array}$ \\
\hline \multirow[t]{4}{*}{ weekly } & Jum'at prayer & $\begin{array}{l}\text { The main hall, the place } \\
\text { of pilgrimage, the hall, } \\
\text { the yayasan terrace }\end{array}$ \\
\hline & $\begin{array}{ll}\begin{array}{l}\text { Friday } \\
\text { pilgrimage }\end{array} & \text { night } \\
\end{array}$ & the place of pilgrimage \\
\hline & The evening bazaar & $\begin{array}{l}\text { Sidewalks and slow } \\
\text { lanes }\end{array}$ \\
\hline & Quran recitation & $\begin{array}{l}\text { The main room of the } \\
\text { mosque }\end{array}$ \\
\hline \multirow[t]{5}{*}{ yearly } & Prayers tarawih & $\begin{array}{l}\text { The main hall, the place } \\
\text { of pilgrimage, the hall, } \\
\text { the yayasan terrace }\end{array}$ \\
\hline & Eid Al-Adha Prayer & $\begin{array}{l}\text { The main hall, the place } \\
\text { of pilgrimage, the hall, } \\
\text { the yayasan terrace }\end{array}$ \\
\hline & Eid prayer & $\begin{array}{l}\text { The main hall, the place } \\
\text { of pilgrimage, the hall, } \\
\text { the yayasan terrace }\end{array}$ \\
\hline & Haul 12 Ramadan & $\begin{array}{l}\text { The main hall, the place } \\
\text { of pilgrimage, the hall, } \\
\text { the yayasan terrace }\end{array}$ \\
\hline & $\begin{array}{l}\text { Haul Habib and } \\
\text { Maulid }\end{array}$ & $\begin{array}{l}\text { The main hall, the place } \\
\text { of pilgrimage, the hall, } \\
\text { the yayasan terrace }\end{array}$ \\
\hline
\end{tabular}




\begin{tabular}{|l|l|l|}
\hline & $\begin{array}{l}\text { breaking the fast } \\
\text { together }\end{array}$ & $\begin{array}{l}\text { The main hall, the place } \\
\text { of pilgrimage, the hall, } \\
\text { the yayasan terrace }\end{array}$ \\
\hline & yearly pilgrimage & the place of pilgrimage \\
\hline
\end{tabular}

Source: Author's Analysis

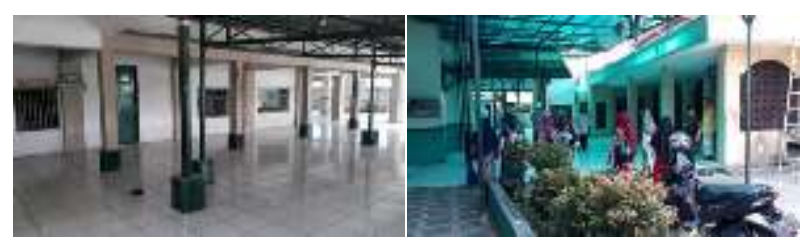

Figure 9. Side hall (left) and Terrace Foundation (right)

\section{Sacred Space Interpretation}

The interpretive part is the final part of the analysis, which expresses the meaning based on the physical and non-physical findings associated with the sacred space. The sacred space of the Jami 'AlMukarromah mosque has a clear definition and is reflected in its physical form. Activities related to the prayer, whether it is five time prayers, Friday prayers, tarawih prayers, and prayers are included in sacred activities. The sacred space used is the main prayer room as the sacred space which has the highest hierarchy. The main prayer room is part of the expansion building. Not the original mosque room.

The sacred space used for pilgrimage activities is different from the sacred space for prayer activities. Sacred space of pilgrimage is on the part adjacent to the tomb and the original part of the mosque which is often called the Nine pillars. The area adjacent to the tomb is an important area so the expansion or renovation of the mosque does not change the original form. The sacred space used for the haul activity is the same as the sacred space for pilgrimage, that is, in the section adjacent to the tomb and pillar of nine

This interpretation is in accordance with Eliade's opinion that 'The sacred space will be created when a sacred thing is manifested into reality, this sacred presence sets apart the cosmic environment that surrounds and makes it different, the embodiment of the sacred idea often influenced by the place factor, something'. Evidently in the mosque of Jami 'AlMukarromah, the sacred part associated with the prayer has a clear physical limit. There is a distinct top scoping between the prayer room and the shrine. On the part used for the pilgrimage is physically restricted to the original mosque building and expansion of the prayer area beside the tomb. More firmly marked by the presence of different colored carpets with carpets used for prayer.

\section{Conclusion}

1. Sacred activities performed in the mosque can be divided into two, namely activities related to prayer (5 time, jum'at, idul fitri, eid adha and tarawih) and activities related to the tomb (pilgrimage, haul)

2. The sacred chambers used have several levels. The sacred space for the highest prayer activity is the main prayer room. The sacred space for the highest activity of the tomb is the Nine pilgrimage / pillar space. Although between the main prayer room and the pilgrimage room are adjacent and have circulation access, the separation of space usage is clear and adhered to by users

3. Sacred space in the mosque Jami 'AlMukarromah has a clear definition and is reflected in its physical form .. Sacred space of pilgrimage is on the part adjacent to the tomb and the original part of the mosque which is often called the pillar of the Nine. The sacred space used for haul activity is the same as the sacred space for pilgrimage, that is, on the part adjacent to the tomb and pillar of Nine

4. The meaning of sacred space obtained from this study in accordance with the opinion of eliade can be seen that in the mosque Jami 'AlMukarromah, sacred part associated with prayer has a clear limit. There is a distinct top scoping between the prayer room and the shrine. 


\section{References}

[1] Ramadhana, Dwindi dan Atyanto Dharoko. (2018). Ruang Sakral dan Profan dalam Arsitektur Masjid Agung Demak, Jawa Tengah. Jurnal INERSIA Vol XIV No 1 Mei 2018

[2] Anisa. (2008). Studi Awal Pola Ruang Kawasan Menara Kudus. Jurnal Arsitektur NALARs Volume 7 Nomor 1 Januari 2008.

[3] Sumalyo. 2006.

[4] Salura, Purnama, Bachtiar Fauzy, Rudy Trisno. (2015). Relasi Liturgi Dengan Ekspresi Bentuk Sakral Arsitektur Gereja Katolik. Kasus Studi : Gereja Katedral, Gereja Theresia, Gereja Salib Suci, Gereja Santo Matias Rasul,Gereja Stella Maris. Proposal Penelitian Hibah Pascasarjana.

[5] Eliade, M., 2002. The Sacred and The Profane. Cetakan pertama. Terjemahan Nurwanto.Yogyakarta: Fajar Pustaka Baru.

[6] Jones, L., 2000. The Hermeneutics of Sacred Architecture. Cambridge, Massachussetts: Harvard University Press

[7] Kanumoyoso, Bondan (2011). Beyond the City Wall. Society and Economic Development in the Ommelanden of Batavia, 1684-1740. Dissertation. De Universiteit Leiden.

[8] Permana, Agus; Mawardi (2017). Habaib in Batavia in the $17^{\text {th }}$ Century. A Study on the Roles of Habaib in the Process of Islamization and Islamic Preaching. Tawarih. International Journal for Historical Studies, 9 (1) October 2017: 23-32. [9] Heuken, SJ, Adolf. (2003). Masjid-masjid tua di Jakarta. Jakarta: Yayasan Cipta Loka Caraka.

[10] Makhmud, Desi Fatmala; Nurhasanah, Fitria; Utami, Indah Ulfia; Khansha, Syifa; Radnawati, Daisy; Syahadat, Ray March (2017). Mewujudkan Kampung Bandan sebagai Kampung Kota Berkelanjutan Menggunakan Pendekatan Asian New Urbanism. Vitruvian Jurnal Arsitektur, Bangunan \& Lingkungan Vol. 6 No. 3 Juni 2017: 91-100.

[11] Widya, Katarina (2012). Studi Bentuk dan Elemen Arsitektur Masjid di Jakarta dari Abad 18 - Abad 20. Jurnal Comtech Vol. 3 No. 2 Desember 2012: 917-927.

[12] Ashadi; Anisa; Nur'aini, Ratna Dewi. (2017). Function, Form, and Meaning of Ritual and Market in Historical Site of Kampung Luar Batang Jakarta Indonesia. International Journal of Research Granthaalayah Vol. 5 (Iss.10): October 2017: 169-178.

[13] Ashadi. (2016). Makna Sinkretisme Bentuk pada Arsitektur Masjid-masjid Walisongo. Disertasi. Program Studi Doktor Arsitektur Sekolah Pascasarjana Universitas Parahyangan.

Http://Repository.Unpar.Ac.Id/Bitstream/Handle/123456789/3 106/Lpd_Purnama\%20salura_Relasi\%20liturgi\%20dengan\%2 0ekspresi-P.Pdf?Sequence $=1 \&$ Isallowed $=Y$

http://www.tribunnews.com/ramadan/2014/07/02/membacasejarah-masjid-al-mukarromah-di-kampung-bandan

http://www.beritasatu.com/destinasi/129951-melongokmakam-tertua-di-masjid-kramat-kampung-bandan.html 